Annals of Warsaw University of Life Sciences - SGGW

Land Reclamation No 48 (1), 2016: 13-26

(Ann. Warsaw Univ. Life Sci. - SGGW, Land Reclam. 48 (1), 2016)

\title{
The water needs of urban green areas
}

\author{
CZESŁAW PRZYBYŁA ${ }^{1}$, DARIUSZ KAYZER ${ }^{2}$, RADOSŁAW GULCZYŃSKI ${ }^{3}$ \\ ${ }^{1}$ Department of Land Improvement, Environmental Development and Geodesy \\ ${ }^{2}$ Department of Mathematical and Statistical Methods \\ ${ }^{3}$ Department of Land Improvement, Environmental Development and Geodesy \\ Poznan University of Life Sciences
}

\begin{abstract}
The water needs of urban green areas. The aim of the research was to evaluate the irrigation needs of urban green spaces in terms of automatic irrigation system. For this purpose, four research stations: two on the surface of shrubs and two on the lawn were founded. The analysis included two vegetation seasons in 2009 and 2010. To estimate the water requirements of the analyzed surfaces a method based on water balance was used. After comparison of simulation result with instrumental results, difference between soil water reserves was calculated. Normalized mean square error (NRMSE) for the post of ornamental shrubs during the vegetation season in 2009 was 0.80 , and $2.76 \%$ for the lawn. However, in the same period in 2010 , it was $0.21 \%$ for ornamental shrubs and $1.54 \%$ for the lawn. The assessment of the irrigation system for the whole operating period was based on indicators of effectiveness and efficiency of irrigation. The performance indicator of irrigation ranged from 83 to $100 \%$, while the rate of irrigation efficiency from 87 to $100 \%$. To assess the relationship between the components of the water balance multiple linear regression model was used. The analysis takes into account the impact of the many independent features on selected dependent feature. For this purpose the impact of temperature, humidity, initial retention in a balance layer, irrigation doses and natural precipitation on the water supply in the soil profiles was analyzed. As a result of the analyzes the size of a single dose of irrigation, in order to maintain a certain level of humidity for different surfaces of urban green areas, can be determined.
\end{abstract}

Key words: water management, urban green areas, irrigation efficiency, water retention

\section{INTRODUCTION}

Irrigation, like soil tillage, mulching, and fertilizing, belongs to the agricultural treatments to improve the structure and physical-water properties of soil. Apart from them, also improvement cutting, in the case of the area planted with ornamental shrubs and all treatments related to the improvement of the lawn, affect the aesthetic appearance of green areas. The irrigation procedure itself, without the use of others, will not bring the expected results. In the case of urban green areas, agricultural practices and improvements, in terms of environmental pollution, salinity, occurring very often a shortage of nutrients and water, and unfavorable soil conditions are of particular importance (Kollender-Szych et al. 2008).

Green areas, despite the important and well-known functions, often do not fulfill their tasks in urban space (Gulczyński and Przybyła 2010). Soils kept in bad culture and developed infrastructure prevent 
ingress of rainwater. This process, combined with frequent rainfall deficiency causes that during the growing, urban green areas have limited access to water sources. In contrast, the phenomenon of surface flow particularly worsen during torrential and heavy rains (Davis and Dukes 2010). When the soil water content rises above field water capacity, the soil will not be able to stop it, it becomes a water gravity and useless for plants (Mocek and Drzymała 2010).

Well-designed, and then maintained greenery fulfills multiple functions: health and biological, aesthetic, socio-educational, economic and scientific (Haber and Urbański 2005). The essence of irrigation is to achieve the desired effect with a minimum dose of water. Irrigation system, under the premise of its operation, has to only supplement natural rainfall, so the system should be cost-effective and economically reasonable (Cepuder and Nolz 2007). In terms of Wielkopolska province, with the unfavorable ratio of evapotranspiration to precipitation, interventional character of irrigation involves uncertainty due to random changes in meteorological factors (Drupka 1976, Przybyła 2000, Łabędzki 2007). Determination of potential evapotranspiration is the basis for calculating the actual evapotranspiration, or evaporation from the soil surface and plant cover, in particular natural conditions (Allen et al. 1998). According to Przybyła (1994) and Kędziora (1999) actual evapotranspiration varies de- pending on meteorological factors, soil (moisture and soil structure, the depth of groundwater), biological (species, the development phase and plant health) and agricultural practices (fertilization intensity and irrigation). Using the results of measurements of the sounders placed at different depths in the soil profile, the water resources of layers of deliberate wetting can be estimated with the sufficient accuracy. In connection with the expansion of the public space, the role of urban green areas will grow, and with them the importance of irrigation systems will increase too (Davis et al. 2009). Efficient use of water will then be a priority, which is why determining the demand for water and its flow control will be of particular importance. Clark (2003) suggested that the limited water resources and high operating costs for urban green areas, causing extensive use of microirrigation systems. The cultivation of ornamental plants, trees and cover crops are covered by drip irrigation system, and for irrigation of lawns depending on the shape and size of land, sprinklers or spray heads are used. Haman et al. (2005) reported that the indices that measure the effectiveness and efficiency of irrigation not only show the needs of aquatic plants, but also achieved growing results. In the case of green areas it results in aesthetics and plant health.

The purpose of the research was to develop a basis for forecasting decade dose of water to maintain a certain level 
of humidity of the soil profile of urban green areas and rational principles of water economy in the conditions of use of irrigation systems.

\section{MATERIAL AND METHODS}

\section{Characteristics of facility and research stations}

Research stations are located in the Botanical Garden of Adam Mickiewicz University in Poznan. This object, located between two arterial roads of the city, fully presents the conditions in urban areas. For the research, four research stations
Basic characteristics of research stations are shown in Table 1. Within the research facility soil profiles with various methods of land management were performed. The conducted soil profiles were sampled for laboratory analysis. Based on the analysis of grain composition, using appropriate equations, water and soil permanents were calculated: field water capacity $(F C)$, refill point $(R P)$ and permanent wilting point $(P W P)$. After entering obtained results using 6.02 RETC program, modeled retention capacity curves $\mathrm{pF}$.

TABLE 1. Characteristics of research stations 1-4

\begin{tabular}{|c|c|c|c|c|c|c|c|c|c|c|}
\hline \multirow{4}{*}{$\begin{array}{l}\text { Station } \\
\text { number }\end{array}$} & \multirow{4}{*}{$\begin{array}{c}\text { Land } \\
\text { develop- } \\
\text { ment }\end{array}$} & \multirow{4}{*}{\begin{tabular}{|c} 
Deliberate \\
wetting \\
layer \\
$\mathrm{H}[\mathrm{cm}]$
\end{tabular}} & \multirow{4}{*}{$\begin{array}{c}\text { Sand } \\
\text { fraction } \\
50-200 \mu \mathrm{m} \\
{[\%]}\end{array}$} & \multirow{4}{*}{$\begin{array}{c}\text { Silt } \\
\text { fraction } \\
2-20 \mu \mathrm{m} \\
{[\%]}\end{array}$} & \multirow{4}{*}{$\begin{array}{c}\text { Clay } \\
\text { fraction } \\
<2 \mu \\
{[\%]}\end{array}$} & \multirow{4}{*}{$\begin{array}{c}\text { Granulo- } \\
\text { metry } \\
\text { Group }\end{array}$} & \multirow{4}{*}{$\begin{array}{c}\text { The utili- } \\
\text { zation rate } \\
\text { of water } \\
\text { generally } \\
\text { available } \\
\text { p [\%] }\end{array}$} & $F C$ & $R P$ & $P W P$ \\
\hline & & & & & & & & \multicolumn{3}{|c|}{$\%$} \\
\hline & & & & & & & & \multicolumn{3}{|c|}{$\mathrm{pF}$} \\
\hline & & & & & & & & 2.0 & 3.0 & 4.2 \\
\hline 1,3 & shrubs & 50 & 81 & 17 & 2 & ps & 60 & 24.0 & 14.3 & 5.6 \\
\hline 2,4 & lawn & 20 & 83 & 15 & 2 & ps & 60 & 22.6 & 13.5 & 15.2 \\
\hline
\end{tabular}

a short distance from each other were founded. They were put in direct sunlight. Two of them were located on the surface of shrubs mulching with agrotextile having a weight of $50 \mathrm{~g} / \mathrm{m}^{2}$ and 5-centimeter layer of pine bark ground, the other two on the lawn. The position is the composition of ornamental shrubs deciduous (Berberis thunbergii DC., Cotoneaster horizontalis Decne.) and coniferous bushes (Taxus baccata L., Larix decidua Mill.) with a maximum height of $3 \mathrm{~m}$ and an average spacing of $1.5 \mathrm{~m}$.
Founded in 2009, the research stations on the lawn and ornamental shrubs planted area have been equipped with an irrigation system. For comparison, stations that not included the irrigation system were founded. In the case of irrigated stations deliberately wetting layers were set out: $0-20 \mathrm{~cm}$ for the lawn and $0-50 \mathrm{~cm}$ for ornamental shrubs. For irrigation of ornamental shrubs the drip system with a diameter of $16 \mathrm{~mm}$ and emitters spaced every $33 \mathrm{~cm}$ was used. The lawn was watered by using a rotary 
sprinkler. The specificity of the process of watering was to deliver everyday low doses of water per day. A single dose of water on the lawn was $1 \mathrm{~mm}$, and on the surface of ornamental shrubs $3.3 \mathrm{~mm}$. In the event of rainfall over $5 \mathrm{~mm}$ rain sensor automatically interrupted watering cycle. One-station battery controller with a solenoid controlled the irrigation system, and a water discharge was measured with a vane-wheel water meter. The measurement of groundwater levels, due to the close proximity of particular stations was performing in one well measured twice a month. Because of the manner of management of analyzed objects and the rooting depth of plants, there was no impact on the analyzed position. Groundwater table was of a depth of 1.5-2.5 m below the ground surface. The research was conducted in 2009-2010. Separated two study periods: from 1 June 2009 to 30 September 2009 and from 1 April 2010 to 30 September 2010.

\section{Balance of water}

Field studies have included measurements of actual soil moisture [\% by volume] continuously. Frequency Domain Reflectometer $(F D R)$ was used for measurement. Probes are placed in the soil profile $0-100 \mathrm{~cm}$, at depths of 10 , $20,40,60$ and $100 \mathrm{~cm}$. Due to the different depth of rooting plants, in the case of lawn, the analysis results of the probes placed on the 10 and $20 \mathrm{~cm}$, and for ornamental shrubs 10, 20 and $40 \mathrm{~cm}$. Data was recorded using separate registrars in hourly intervals.

On the basis of measurements, daily water balance was determined:

$$
R_{i-1}+P r_{i}+H d_{i}-R_{i}-H o_{i}-E T_{A i}=0
$$

where:

$R_{i-1}-$ initial retention [mm],

$\operatorname{Pr}_{i}$ - precipitation [mm],

$H d_{i}$ - dose of irrigation [mm],

$R_{i}$ - final retention [mm],

$\mathrm{Ho}_{i}$ - outflow outside the balancing [mm],

$E T_{A i}$ - actual evapotranspiration (and $i$ symbol of the day) [-].

The measure of the field water consumption $\left(S_{i}\right)$ is the sum of daily $\left(E T_{A i}\right)$ and outflow of water $\left(\mathrm{Ho}_{i}\right)$.

\section{Effectiveness evaluation} and the effectiveness of irrigation

Indicators of the effectiveness and efficiency of irrigation were calculated for stations from lawn and shrubs for the entire growing season. Effectiveness evaluation of irrigation dose selection was carried out based on the following formula:

$$
I A=\frac{\sum_{i}\left(E T_{A i}-\left(W A_{i}-R U\right)\right)}{E T_{A}} \cdot 100
$$

where:

$I A$ - effectiveness evaluation,

$E T_{A}$ - we set as the sum of actual evapotranspiration for the entire growing period,

$W A_{i}-$ actual soil moisture, 
$R U$ - available water capacity, $W A_{i}-R U-$ range of water inaccessible to plants (for another day of vegetation).

Irrigation efficiency is described by formula:

$$
S E=\frac{\sum_{i}\left(H d_{i}-S L_{i}\right)}{H d} \cdot 100
$$

where:

$S E$ - efficiency of irrigation [-],

$H d_{i}-S L_{i}-$ loss of water caused by irrigation due to exceeding deliberate wetting layer (for another day of growing season) $[\mathrm{mm}]$,

$H d$ - sum of doses of irrigation for the entire growing period.

\section{Evaluation of retention changes}

The relationship between the changes in retention $\left[\Delta R_{t}=\left(R_{t}-R_{t-1}\right)\right]$ and decadal average temperature $\left(T_{t}\right)$, decadal average insufficiency $\left(D_{t}\right)$, initial retention $\left(R_{t-1}\right)$, decadal sum of irrigation water doses $\left(H d_{t}\right)$ and decadal rainfall $\left(P r_{t}\right)$ is presented in the form of a linear multiple regression model expressed as:

$$
\begin{aligned}
\Delta R_{t} & =\beta_{0}+\beta_{1} T_{t}+\beta_{2} D_{t}+\beta_{3} R_{t-1}+\beta_{4} H d_{t}+ \\
& +\beta_{5} \operatorname{Pr}_{t}+e
\end{aligned}
$$

where:

$\beta_{0}, \beta_{1}, \beta_{2}, \ldots, \beta_{5}$ - regression coefficients, $e$-random error.

Statistical analysis was performed using Statistica 9.0 package. The accuracy of the forecasts proposed in the model was evaluated on the basis of symmetric measures of normalized mean square error (NRMSE). It takes into account equally underestimation and overestimation of forecast volatility. In the present case NRMSE defines the differences between the measured and calculated soil water supplies.

\section{RESULTS AND DISCUSSION}

\section{Weather conditions of facility}

Table 2 shows the amount of rainfall and mean temperature on the background data and multi-year study period. The average of the period 1971-2000 are given for post IMGW Poznań-Ławica, and meteorological data from the remaining term derived from meteorological stations located throughout the test facility conducted by VIEP in Poznan.

TABLE 2. Meteorological conditions of research facility

\begin{tabular}{|l|c|c|}
\hline Growing season & $\begin{array}{c}\text { Total rainfall } \\
\operatorname{Pr}[\mathrm{mm}]\end{array}$ & $\begin{array}{c}\text { Average } \\
\text { temperatures } \\
{\left[{ }^{\circ} \mathrm{C}\right]}\end{array}$ \\
\hline 2009 (1 IV-30 IX) & 390.2 & 16.1 \\
\hline 2010 (1 IV-30 IX) & 413.2 & 15.6 \\
\hline 1971-2000 (IV-IX) & 340.0 & 14.2 \\
$2005-2010$ (IV-IX) & 333.0 & 15.9 \\
\hline
\end{tabular}

In order to determine the water retention of soils with respect to vegetation creating urban green basic meteorological conditions in the area were indicated. In the period 2009-2010, both growing seasons were classified into wet by Kaczorowska (1962). 


\section{Balance of water facility}

The conducted research shows the dynamics of changes of soil moisture profiles depending on weather conditions, particularly rainfall and the intensity of irrigation. During the research period variable dynamics of water reserves in the soil profiles (Figs. 1-3) were observed. Larger fluctuations of retention occurred at positions located on the lawn (Fig. 1B, Fig. 2). It should be emphasized that despite the high precipitation in vegetation seasons in multi-year, supplies of water did not exceed the value with field water capacity $(F C)$ and remained below the refill point values $(R P)$ and were approaching the permanent wilting point $(P W P)$. In the case of the profile of the lawn such a process was observed during 2009, when in the second decade of August, water supplies were below critical humidity, and the decrease in retention lasted until the end of the growing season (Fig. 1B). In 2010, on the surface of the non-irrigated lawn a decline of water supplies below the permanent wilting point (Fig. 2) was noticed. In the first and second decade of July only $6.4 \mathrm{~mm}$ of precipitation was measured. For the station of ornamental shrubs (Fig. 3) on the irrigated area, this decline did not exceed the critical humidity, but on non-irrigated surface water supplies have fallen below the critical humidity and approached the level of the permanent wilting point. Sudden rainfall in the third decade of July amounting to $62.6 \mathrm{~mm}$ caused a substantial restora- tion of water supplies for all research positions. In the case of non-irrigated stations, water reserves have increased, in the case of lawn $12.8 \mathrm{~mm}$, while on the surface of ornamental shrubs about $8.8 \mathrm{~mm}$. Analyzing this situation we can not forget about the outflow of water from the area covered by balancing. Due to the relatively small thickness, of $20 \mathrm{~cm}$, more prone to water loss because of that was a lawn. Loss of water for irrigated station amounted to $25.5 \mathrm{~mm}$ and $23.4 \mathrm{~mm}$ for non-irrigated station. At the stations of ornamental shrubs, which analyzed thickness is $50 \mathrm{~cm}$, the outflow occurred only in irrigated variant and was only $3.5 \mathrm{~mm}$. In the following months as a result of high rainfall: in August $126.9 \mathrm{~mm}$ and September $67.8 \mathrm{~mm}$ gradual restoration of retention for all examined stations occurred. On irrigated positions, the value of stocks of water were close to field water capacity, while on non-irrigated exceeded the value of the critical humidity. In the calculated water balance increased water consumption was observed in irrigated areas. Retention difference between irrigated and non-irrigated lawns was $18 \%$, while between irrigated and non-irrigated surface of ornamental shrubs was $20 \%$. An important factor affecting water consumption was the process of evapotranspiration. Additionally outflow coefficient was analyzed, expressed as the ratio - the quantity of water seeping out of the balancing area $(H o)$ to the used water $(S)$. The research found that it was higher for 


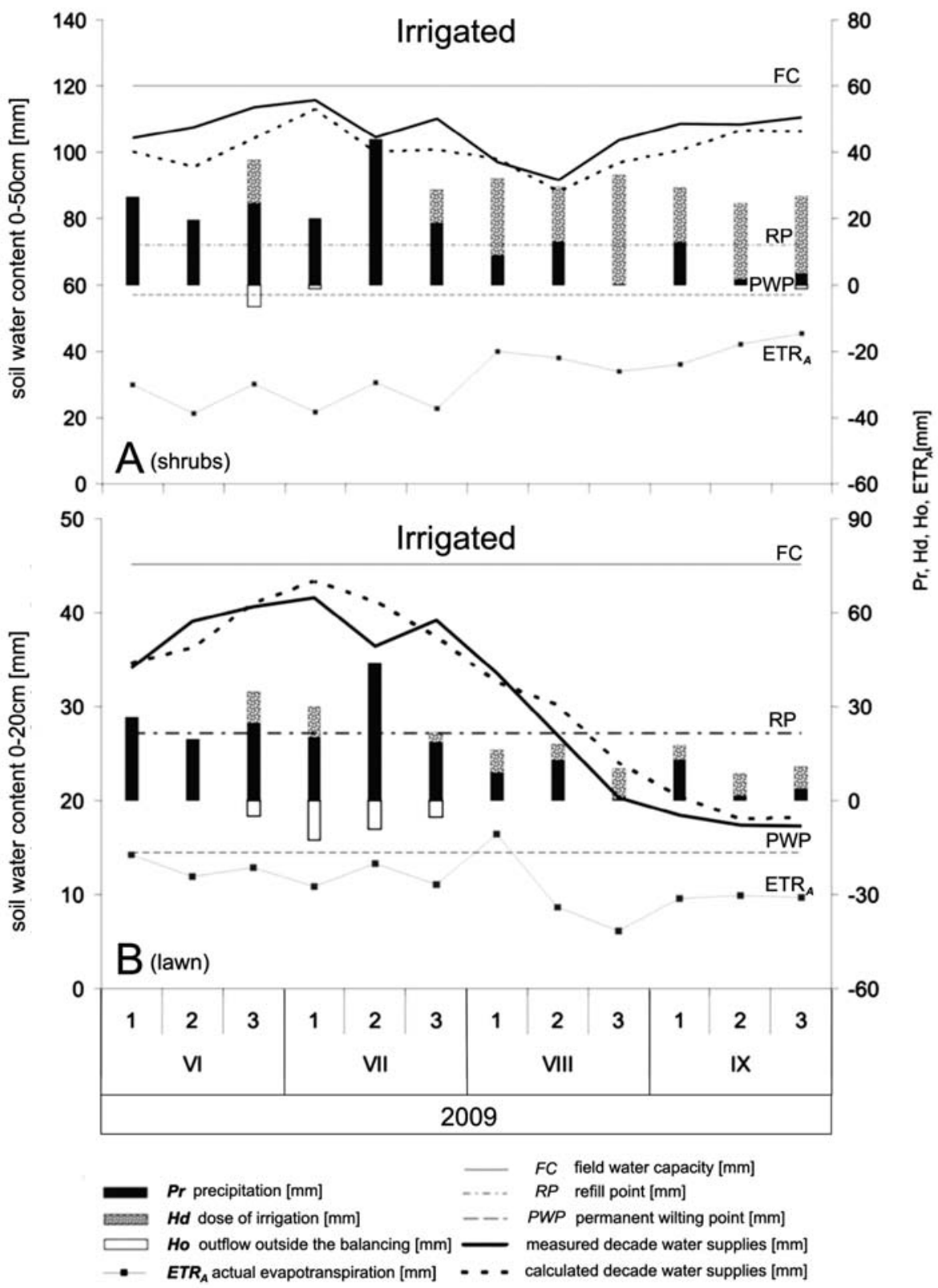

FIGURE 1. Calculated and measured decade water supplies in irrigated ornamental shrubs profiles (A) and lawn (B) in the vegetation period 2009, on the background of inventories with field water capacity $(F C)$, refill point $(R P)$ and permanent wilting point $(P W P)$. The graph shows the decade of precipitation $(P r)$, actual evapotranspiration taking into account the rate $K s\left(E T R_{A}\right)$, the dose of water $(H d)$ and outflow beyond the scope of deliberate wetting layer $(\mathrm{Ho})$ 


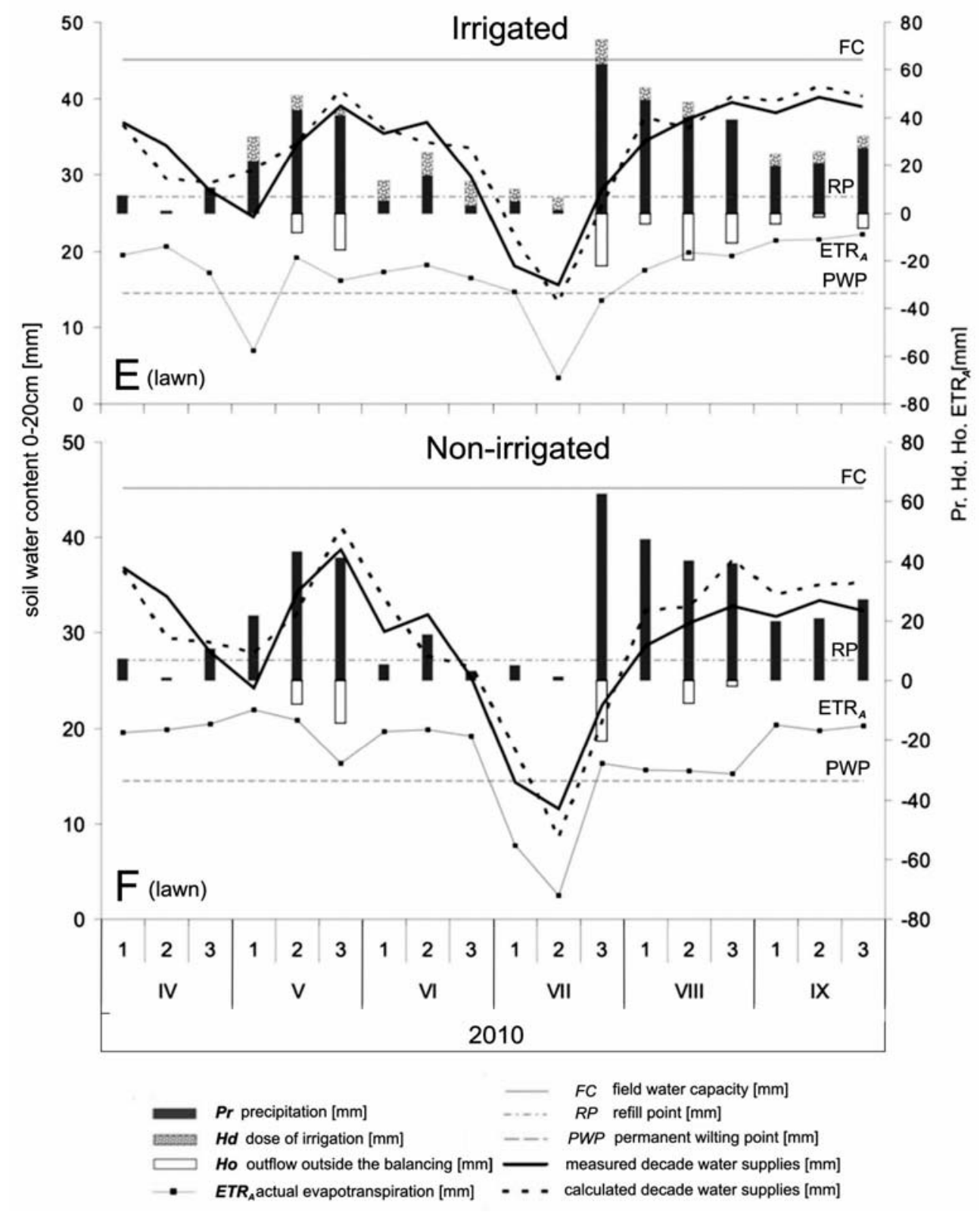

FIGURE 2. Calculated and measured decade water supplies in irrigated lawn profile (E) and non-irrigated lawn profile (F) during the growing season 2010 on the background of inventories with field water capacity $(F C)$, refill point $(R P)$ and permanent wilting point $(P W P)$. The graph shows the decade of precipitation $(\mathrm{Pr})$, the actual evapotranspiration taking into account rate $K S\left(E T R_{A}\right)$, the dose of water $(H d)$ and outflow beyond the scope of deliberate wetting layer $(\mathrm{Ho})$ 


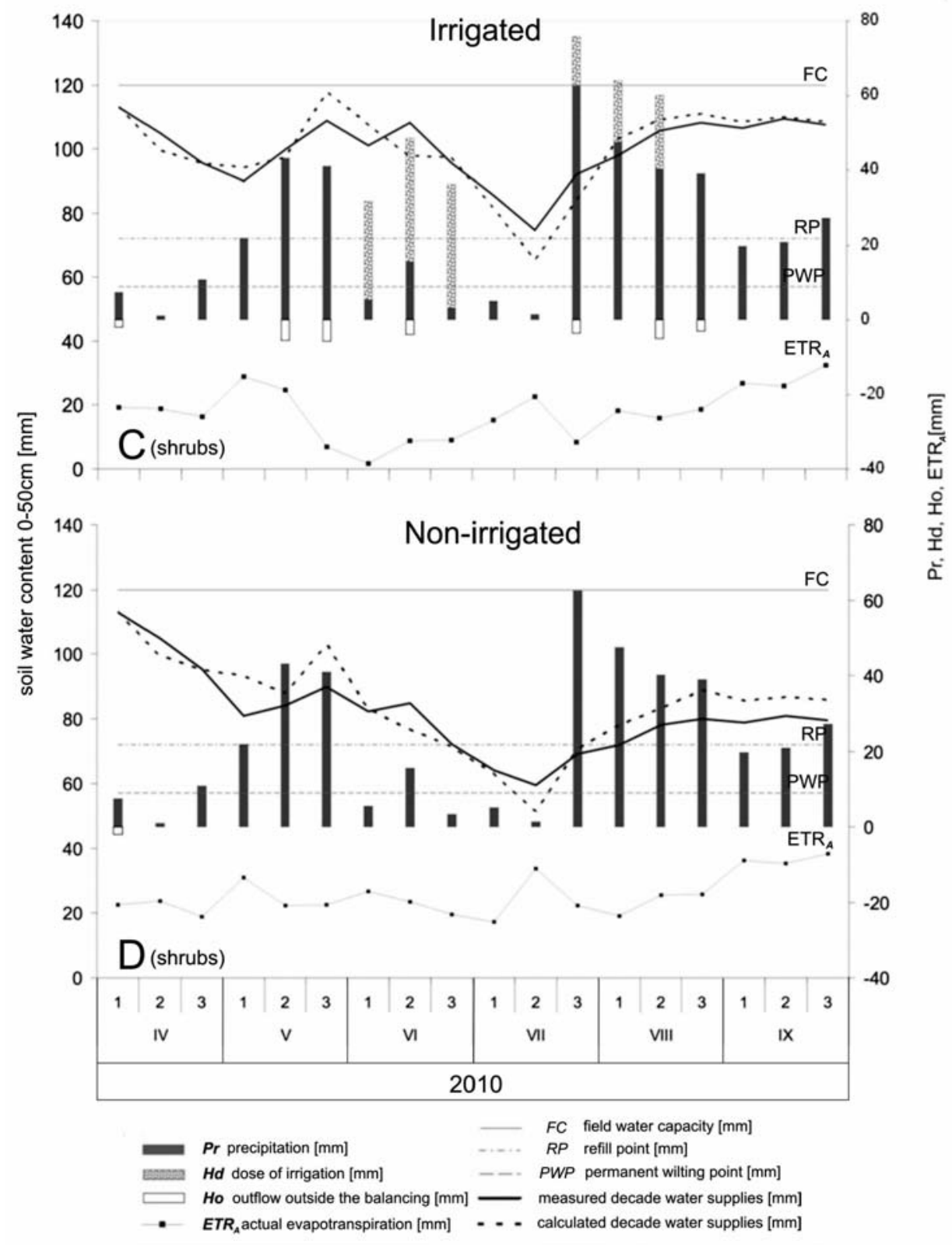

FIGURE 3. Calculated and measured decade water supplies in irrigated ornamental shrubs profile (C) and non-irrigated ornamental shrubs profile (D) during the growing season 2010 on the background of inventories with field water capacity $(F C)$, refill point $(R P)$ and the permanent wilting point $(P W P)$. The graph shows the decade of precipitation $(P r)$, the actual evapotranspiration taking into account rate $K s$ $\left(E T R_{A}\right)$, the dose of water $(H d)$ and outflow beyond the scope of deliberate wetting layer $(\mathrm{Ho})$ 
lawn and ranged from 0.12 on non-irrigated station to 0.29 on irrigated one. On the irrigated area of ornamental shrubs it amounted to 0.23 , while on the non-irrigated did not occur.

\section{Evaluation of irrigation system}

Evaluation of irrigation system performance (Table 3) was based on indicators of effectiveness and efficiency of irrigation. The adopted criteria allow to specify objectively the validity and efficacy of the irrigation system.

TABLE 3. Evaluation of the efficiency and effectiveness of irrigation

\begin{tabular}{|l|c|c|c|c|}
\hline \multirow{2}{*}{$\begin{array}{l}\text { Land } \\
\text { develop- } \\
\text { ment }\end{array}$} & \multicolumn{2}{|c|}{$\begin{array}{c}\text { Evaluation of the } \\
\text { efficiency of } \\
\text { irrigation [\%] }\end{array}$} & \multicolumn{2}{|c|}{$\begin{array}{c}\text { Evaluation of the } \\
\text { effectiveness of } \\
\text { irrigation [\%] }\end{array}$} \\
\cline { 2 - 5 } & 2009 & 2010 & 2009 & 2010 \\
\hline $\begin{array}{l}\text { Ornamen- } \\
\text { tal shrubs }\end{array}$ & 100 & 99 & 100 & 97 \\
\hline Lawn & 28 & 46 & 90 & 100 \\
\hline
\end{tabular}

The rate of success is oriented to assess the dose selection of irrigation in relation to evapotranspiration. The studies demonstrated significant differences in its values. Very high efficiency irrigation treatment was obtained on the surface of ornamental shrubs. Significantly less than from 28 to $46 \%$ was obtained at the same time for the lawn. Such a situation is explained not only by different thicknesses of balance layer stations, but also more intense depletion of water resources from deliberate wetting layer of the lawn than from the surface of ornamental shrubs. Irrigation efficiency index for the tested stations did not differ signifi- cantly, and its high value resulted from the frequency of administration of small doses of water. It should be emphasized that rainfall had a significant impact on the results of the efficiency of irrigation. It was observed that the efficiency of irrigation was lower during the rainy season. However, what is surprising it has not affected significantly the irrigation effectiveness rate. The average value of the irrigation effectiveness rate in a similar irrigation control system ranged from 79 to $99 \%$, while the efficiency of irrigation from 58 to $87 \%$ (Davis and Dukes 2010). However, in McCready and Dukes studies (2011) irrigation effectiveness rate estimated from 89 to $100 \%$, while the efficiency of irrigation from 81 to $98 \%$.

\section{Prediction of optimal water doses}

To investigate the relationships between the components of the water balance multiple linear regression model was used. Features of multiple regression are presented in Table 4. Irrigated and non-irrigated areas, various forms of development of green areas, are included in one regression model. In the case of lawn coefficient of determination for assessing the change in retention amounted to 0.65 , while for the area of ornamental shrubs 0.51 .

The NRMSE for the profile of ornamental shrubs during the growing season of 2009 was 0.80 , and $2.76 \%$ for the lawn. In turn, during the growing season in $2010,0.21 \%$ for shrubs and $1.54 \%$ for 
TABLE 4. The coefficients of determination for the model

\begin{tabular}{|l|c|c|c|c|c|}
\hline Land development & Dependent variable & Independent variables & $\begin{array}{c}R^{2} \\
{[\%]}\end{array}$ & $p$-value & $\begin{array}{c}\text { NRMSE } \\
{[\%]}\end{array}$ \\
\hline Ornamental shrubs & $R_{t}-R_{t-1}$ & $T_{t}, D_{t}, R_{t-1}, H d_{t}, P r_{t}$ & 51 & $<0.001$ & 0.14 \\
\hline Lawn & $R_{t}-R_{t-1}$ & $T_{t}, D_{t}, R_{t-1}, H d_{t}, P r_{t}$ & 54 & $<0.001$ & 1.11 \\
\hline
\end{tabular}

the lawn. In a similar study McCready and Dukes (2011) report that the difference NRMSE amounted to $1.54 \%$. The biggest differences between calculated, and measured soil water supplies were recorded during the periods when the humidity was above current field water capacity $(F C)$, as was the case with periods of heavy rainfall. different from 0 due to the high amount of the rainfall. Due to conducted analysis coefficients, which can be used to determine the approximate decade dose of water were obtained. Regression coefficients for the surface of the ornamental shrubs and the lawn are shown in Table 5. In the regression equation on the surface of ornamental shrubs and

TABLE 5. Results of multiple regression for surface ornamental shrubs (S) and lawn (L)

\begin{tabular}{|c|c|r|r|r|r|r|r|}
\hline \multirow{2}{*}{ Independent variable } & \multicolumn{2}{|c|}{$\beta$} & \multicolumn{2}{c|}{ Standard error $\beta$} & \multicolumn{2}{c|}{$p$-value } \\
\cline { 3 - 8 } & & $\mathrm{S}$ & $\mathrm{L}$ & $\mathrm{S}$ & $\mathrm{L}$ & $\mathrm{S}$ & $\mathrm{L}$ \\
\hline$\beta_{0}$ & $\times$ & 17.17 & -1.82 & 10.70 & 3.97 & 0.11 & 0.64 \\
\hline$\beta_{l}$ & $T_{t}$ & -0.64 & 0.02 & 0.33 & 0.18 & 0.06 & 0.88 \\
\hline$\beta_{2}$ & $D_{t}$ & 0.76 & -0.18 & 1.01 & 0.34 & 0.45 & 0.60 \\
\hline$\beta_{3}$ & $R_{t-1}$ & -0.20 & -0.11 & 0.08 & 0.07 & 0.01 & 0.11 \\
\hline$\beta_{4}$ & $H d_{t}$ & 0.38 & 0.18 & 0.11 & 0.14 & $<0.001$ & 0.22 \\
\hline$\beta_{5}$ & $P r_{t}$ & 0.35 & 0.45 & 0.06 & 0.05 & $<0.001$ & $<0.001$ \\
\hline
\end{tabular}

The biggest influence on the coefficient of determination was precipitation, which did not allow to determine the actual impact of the irrigation on soil moisture. Due to the high amount of rainfall differences between irrigated and non-irrigated stations were not significant. The average temperature and an average humidity deficiency, illustrating the impact of the actual evapotranspiration proved to be not significantly the lawn, precipitation had a significant impact on the $\Delta R_{t}$ change. In the case of surface of shrubs the dose of water and the condition of the initial retention were also statistically significant. These results indicate the advisability of pursuing further studies, collect and process information and their inclusion in the regression analysis.

Finally, the selection equation decade dose of water takes the form of:

$$
H d_{t}=\frac{1}{\beta_{4}}\left(R_{o p t}-R_{t-1}-\beta_{0}-\beta_{1} T_{t}-\beta_{2} D_{t}-\beta_{3} R_{t-1}-\beta_{5} P r_{t}\right)
$$


Determination of the dose decade of water to maintain a certain level of humidity areas landscaping is done through the designated optimum retention $\left(R_{o p}\right)$.

Optimal retention depending on the intended effects and irrigation needs may be from 70 to $90 \%$ of field capacity of water. Change of retention $\left(\Delta R_{t}\right)$ from regression equation has been replaced by the difference between the optimum retention and initial retention of the balancing period $\left(R_{o p t}-R_{t-1}\right)$.

Substituting obtained from the regression analysis equation coefficients decade selection water dose on the surface of shrubs is: of the potential evapotranspiration, the result is improved by using appropriate factors specific for individual ways of development of green areas. The specificity of irrigation of green areas is the selection of appropriate methods of irrigation in relation to the diverse forms of development. Irrigation of urban green areas includes: recreation lawns, sports and entertainment lawns, as well as surface cover crops, flower beds, shrubs and trees. Their irrigation uses spray heads, rotary sprinklers, sprinklers to root, rotors and drip lines (Irrigation Association 2008). Therefore, well designed green area is one in which, in ad-

$$
H d_{t}=\frac{1}{0.38}\left(R_{o p t}-R_{t-1}-17.17+0.64 T_{t}-0.76 D_{t}+0.20 R_{t-1}-0.35 P r_{t}\right)
$$

And for the lawn:

$$
H d_{t}=\frac{1}{0.18}\left(R_{o p t}-R_{t-1}+1.82-0.02 T_{t}+0.18 D_{t}+0.11 R_{t-1}-0.45 \operatorname{Pr}_{t}\right)
$$

Using the above equation, and featuring a publicly available meteorological data, the dosage of water to maintain a certain humidity level of the soil profile can be calculated. This way of calculating the dose of irrigation can be helpful, not only for existing green areas, but also in determining water needs at the design stage. Similarly, the control of the irrigation is performed by control equipment of evapotranspiration process (Haley et al. 2007, Devitt et al. 2008). In the used method after the calculation dition to aesthetics, its functionality and efficiency are crucial. The above effects can not be achieved without executing the analysis of soil and without installing on-site soil moisture measurement system (McCready and Dukes 2011). The use of automatic metering systems increases efficiency and reduces consumption of irrigation water from 11 to $75 \%$ compared to manual irrigation systems (Salvador et al. 2011). These savings result mainly from water seepage control outside the deliberate wetting. 


\section{CONCLUSIONS}

The technique of low single doses of water a day, more proven in the case of irrigation of ornamental shrubs. Actually, irrigation time management using rainfall sensor gives similar savings in irrigation as the use of evapotranspiration process control equipment. Indicators of effectiveness and efficiency of irrigation are decisive importance here. Difficulty in applying the presented method is the need to assess the dose of irrigation on the basis of meteorological data and the initial retention state in order to maintain a certain level of moisture of the soil profile. As a result of the multiple regression analyzes a lawn area that the coefficient of determination was $54 \%$ performed better fitting model, for the area of plants coefficient of determination was lower and amounted to 51\%. Normalized mean square error (NRMSE) during research for a profile with shrubs amounted to $0.14 \%$, while for the profile of lawn $1.11 \%$. Satisfactory NRMSE and $R^{2}$ rates show that the applied method can be used in practice, and the results should be treated as orientation for further research in the field of rational water management in urban green areas.

\section{REFERENCES}

ALLEN R.G., PEREIRA L.S., RAES D., SMITH M. 1998: Crop evapotranspiration: Guidelines for computing crop requirements. Irrigation and Drainage 56, FAO, Rome, Italy.

CEPUDER P., NOLZ R. 2007: Irrigation management by means of soil moisture sensor technologies. Journal of Water Land Development 11, 79-90.
CLARK G.A. 2003: Microirrigation in the landscape. Gainesville, FL. Electronic Data Information Source of UF/IFAS Extension.

DAVIS S.L., DUKES M.D. 2010: Irrigation scheduling performance by evapotranspiration-based controllers. Agricultural Water Management 98: 19-28.

DAVIS S.L., DUKES M.D., MILLER G.L. 2009: Landscape irrigation by evapotranspiration - based irrigation controllers under dry conditions in Southwest Florida. Agricultural Water Management 96, 1828-1836.

DEVITT D.A., CARSTENSEN K., MORRIS R.L. 2008: Residental Water Savings Associated with Satellite-Based ET Irrigation Controllers. Journal of Irrigation and Drainage Engineering 134, 1(74), 74-82.

DRUPKA S. 1976: Technical and agricultural exploitation of irrigation machnes. PWRiL, Warszawa.

GULCZYŃSKI R., PRZYBYŁA Cz. 2010: Costs of construction and operation of irrigation systems in recreation and sports areas. Journal of Water Land Development 14, 101-113.

HABER Z., URBAŃSKI P. 2005: Landscape architecture and ecology. Wydawnictwo Akademii Rolniczej im. A. Cieszkowskiego w Poznaniu, Poznań.

HALEY M.B., DUKES M.D., MILLER G.L. 2007: Residental Irrigation Water Use in Central Florida. Journal of Irrigation and Drainage Engineering 133, 5(427).

HAMAN D.Z., SMAJSTRLA A.G., PITTS, D.J. 2005: Efficiencies of irrigation systems used in Florida nurseries. Gainesville, FL. Electronic Data Information Source of UF/IFAS Extension.

Irrigation Association 2008: Smart Water Application Technology (SWAT) turf and landscape irrigation equipment testing protocol for climatologically based controllers; 8th draft testing protocol. The Irrigation Association, Falls Church, VA. Available from: http://irrigation.org/SWAT/swat.aspx?id=302 \&terms $=$ swat + protocol.

KACZOROWSKA Z. 1962: Precipitation in Poland. Prace Geograf., PAN 33.

KĘDZIORA A. 1999: Fundation of Agrometeorology. PWRiL, Poznań (in Polish). 
KOLLENDER-SZYCH A., NIEDŹWIECKI E., MALINOWSKI R. 2008: Urban soils. Wydawnictwo Naukowe Akademii Rolniczej w Szczecinie, Szczecin.

ŁABĘDZKI L. 2007: Irrigation in Poland - current status after reforms in agriculture and future development. Journal of Water Land Development 11, 3-16.

McCREADY M.S., DUKES M.D. 2011: Landscape irrigation scheduling efficiency and adequancy by various control technologies. $A g$ ricultural Water Management 98, 697-704.

MOCEK A., DRZYMAŁA S. 2010: Genesis, analysis and classification of soils. Wydawnictwo Uniwersytetu Przyrodniczego w Poznaniu, Poznań (in Polish).

PRZYBYŁA Cz. 1994: Real evapotranspiration in the scheduling of sprinkling irrigation systems. Roczniki Akademii Rolniczej 257, 255-262

PRZYBYŁA Cz. 2000: Irrigation needs and irrigation problems in Wielkopolska region. International Conference. Present and future reqiurements for agrometeorological information. Poznań-Sielinko, 11-15.09.2000. Israel Meteorological Service, 69-74

SALVADOR R., BAUTISTA-CAPETILLO C., PLAYÁN E. 2011: Irrigation performance in private urban landscapes: A study case in Zaragoza (Spain). Landscape and Urban Planning 100, 3, 302-311.

Streszczenie: Potrzeby wodne miejskich terenów zieleni. Celem badań była ocena potrzeb nawadniania miejskich terenów zieleni w warunkach zastosowania automatycznego systemu nawadniającego. W tym celu założono cztery stanowiska badawcze: dwa na powierzchni krzewów ozdobnych oraz dwa na trawniku. Analizą objęto dwa okresy wegetacyjne w latach 2009 i 2010. Do oszacowania potrzeb wodnych badanych powierzchni badawczych zastosowano metodę wykorzystującą bilans wodny. Po zestawieniu wyników symulacji $\mathrm{z}$ wynikami pomiarowymi obliczono różnice zapasów wody glebowej. Znormalizowany błąd średniokwadratowy (NRMSE) dla stanowiska z krzewami ozdobnymi podczas okresu wegetacji w 2009 roku wyniósł 0,80\%, a dla trawnika NRMSE wyniosło $2,76 \%$, z kolei w analogicznym okresie w 2010 roku wyniósł odpowiednio 0,21 i $1,54 \%$. Ocenę pracy systemu nawadniania dla całego okresu eksploatacji przeprowadzono na podstawie wskaźników skuteczności i efektywności nawadniania. Wartość wskaźnika skuteczności nawadniania wahała się od 83 do $100 \%$, a wskaźnika efektywności nawadniania od 87 do $100 \%$. Dla oceny związku między składnikami bilansu wodnego wykorzystano liniowy model regresji wielokrotnej. Przeprowadzona analiza uwzględniała wpływ wielu cech niezależnych na wybraną cechę zależną. W tym celu badano wpływ temperatury i niedosytu powietrza, wilgotności, retencji początkowej w warstwie bilansowanej, dawki nawadniania oraz opadu naturalnego na zapasy wody w profilach glebowych. W efekcie przeprowadzonych analiz można ustalić wielkość jednorazowej dawki nawodnieniowej w celu utrzymania określonego poziomu uwilgotnienia dla różnych powierzchni miejskich terenów zieleni.

Stowa kluczowe: gospodarowanie wodą, tereny zieleni miejskiej, efektywność nawodnień, retencja wodna

\section{MS. received February 2016}

\section{Author's addresses:}

Czesław Przybyła, Radosław Gulczyński

Uniwersytet Przyrodniczy w Poznaniu

Wydział Melioracji i Inżynierii Środowiska

Instytut Melioracji, Kształtowania Środowiska i Geodezji

Zakład Gospodarowania Wodą i Ekonomiki

Inżynierii Środowiska

ul. Piątkowska 94, 60-649 Poznań

Poland

e-mail: czprzybyla@up.poznan.pl radekgulczynski@gmail.com

Dariusz Kayzer

Uniwersytet Przyrodniczy w Poznaniu

Katedra Metod Matematycznych i Statystycznych Zakład Biostatystyki

ul. Wojska Polskiego 28, 60-637 Poznań

Poland

e-mail: dkayzer@up.poznan.pl 